\title{
Pandangan Dunia Evolusioner dan Respon Iman Kristen
}

\author{
Stella Y.E. Pattipeilohy ${ }^{1}$, John C. Simon ${ }^{2}$ \\ ${ }^{1}$ Fakultas Teologi, Universitas Kristen Duta Wacana \\ ${ }^{2}$ Sekolah Tinggi Teologi Indonesia Timur Makassar \\ 12exlentyapattipeilohy@yahoo.com, johnsimon@sttintimlib.ac.id
}

\begin{abstract}
The evolutionary worldview confirms its position since the discovery of various ancient human sites, and continues to develop with various genetic engineerings and protein discoveries as well as advances in the field of artificial intelligence (AI) technology. Initially the religious community was the party who felt most attacked by the theory of evolution because it stripped the Bible of the truth about the creation of the world and humans. Later some Catholic Church appreciative statements about the theory of evolution and the big bang theory, including Pierre Teilhard de Chardin's attempt to explain the evolution of human consciousness towards the cosmic Christ, showed a change in religion towards acceptance of the diversity of world views: religion, culture and science. This evolutionary world development raises ethical questions about what is religion's contribution. One of them is the awareness about shadow. The awareness is derived from religion which teaches that men are created by God that even though unique, but mortal and finite creations. Shadow is liberation so that men are not shackled to matter. He is a fragile human who longs to evolve to be a Christ as the perfect human image.
\end{abstract}

Key words: Christian faith; cosmic Christ; evolutionary worldview; shadow

\begin{abstract}
Abstraksi: Pandangan dunia evolusioner meneguhkan kedudukannya sejak penemuan berbagai situs manusia purba, dan terus berkembang dengan berbagai penemuan rekayasa genetik dan protein dan kemajuan di bidang teknologi artificial intelligence (AI). Semula kalangan agama menjadi pihak yang merasa paling diserang dengan teori evolusi karena melucuti kebenaran Alkitab tentang penciptaan dunia dan manusia. Belakangan beberapa pernyataan apresiatif Gereja Katolik terhadap teori evolusi dan teori big bang, termasuk usaha Pierre Teilhard de Chardin menjelaskan tentang evolusi kesadaran manusia menuju Kristus kosmis, memperlihatkan perubahan agama menuju penerimaan akan keragaman pandangan dunia: agama, budaya dan ilmu pengetahuan. Perkembangan dunia evolusioner ini memperhadapkan berbagai pertanyaan etis tentang apa sumbangan agama. Salah satunya adalah kesadaran tentang bayangan. Kesadaran akan bayangan diperoleh dari agama yang mengajarkan bahwa manusia yang diciptakan Tuhan, sekalipun unik, adalah ciptaan yang fana dan terbatas. Bayangan adalah pembebasan agar manusia tidak tertambat pada materi. Ia adalah manusia yang rapuh yang merindukan berevolusi menuju Kristus sebagai gambaran manusia yang sempurna.
\end{abstract}

Kata kunci: bayangan; iman Kristen; Kristus kosmis; pandangan dunia evolusioner

\begin{tabular}{llll}
\hline Article History : & Received: 28-01-2018 & Revised: 04-03-2018 & Accepted: 08-04-2019
\end{tabular}




\section{Pendahuluan}

Ada semacam prior knowledge yang membingkai latar belakng artikel ini, yang berasal dari surat kabar Kompas. Pertama, dari tulisan Haidar Bagir berjudul "Pendidikan Manusia Vs Kecerdasan Buatan" yang terbit pada 15 September 2018. ${ }^{1}$ Revolusi keempat yang sedang kita alami saat ini, menurut Bagir, antara lain makin menyempurnakan teknologi "kecerdasan buatan" (artificial intelligence; AI) yang kecepatannya makin menyamai kecepatan kerja otak manusia, bahkan berkemungkinan melampauinya. Jika sudah demikian, apa yang masih tersisa pada manusia yang membedakannya dengan AI tersebut? Pertanyaan ini belum akan saya jawab, karena menjadi bagian utama tulisan ini ketika membicarakan tentang teori evolusi Darwin dan usaha Teilhard de Chardin merefleksikannya.

Kedua, pada 15 September 2018 itu juga, Kompas menurunkan sebuah tulisan Budiman Sudjatmiko berjudul “Inovasi dalam Revolusi 4.0”. ${ }^{2}$ Tulisan ini menarik karena menjelaskan kecepatan komputer yang terus meningkat mengikuti hukum Moore dengan fungsi yang kian mendekati otak manusia. Kemajuan neuroscience (ilmu saraf) pun sedang berusaha mengunggah kesadaran (memori dan rasa) manusia ke perangkat digital sehingga memungkinkan kesadaran manusia melampaui batasan-batasan fisik. Teknologi keempat yang segera muncul adalah kemajuan rekayasa genetika yang memungkinkan lahirnya manusia serba super dan serba sehat tanpa meninggalkan tubuh fisiknya. Lantas Sudjatmiko mengajukan pertanyaan etis, "ke mana arah gelombang transformasi ini membawa masyarakat?"

Pertanyaan etis di atas sejatinya mewakili kebanyakan orang yang sedang menggugat perubahan yang sedang terjadi. Baik atas nama alasan-alasan rasional, hingga berupa ketidaksukaan dan ketidaksiapan untuk berubah dengan menggunakan argumen-argumen keagamaan yang sempit. Jawaban atas pertanyaan etis tersebut secara jelas memperlihatkan ketegangan antara ilmu dan iman. Jawaban ilmu mewakili kutup yang dianggap pro perubahan, dan jawaban iman mewakili kutup yang kontra perubahan. Kendatipun mereka yang berada di kubu sains tidak otomatis terbuka, mana kala yang terjadi adalah saintisme ${ }^{3}$ atau creation-science, ${ }^{4}$ yaitu menempatkan sains di bawah agama dengan jalan membaca teks-teks Kitab Kejadian mengenai penciptaan secara harfiah. Di antara pro dan kontra itu sejatinya terdapat ruang di mana keduanya sama-sama hendak menegaskan peran tertentu di ranah publik.

Tesis tulisan ini adalah bahwa perkembangan evolusioner membutuhkan sikap baru iman Kristen dengan terbuka pada dialog dengan ilmu karena keduanya samasama ingin menolong manusia melampaui dunia materi sebagai bayangan tentang

${ }^{1}$ Haidar Bagir, "Pendidikan Manusia Vs Kecerdasan Buatan," Kompas (Jakarta, September 15, 2018),

23udiman Sudjatmiko, “Inovasi Dalam Revolusi 4.0," Kompas (Jakarta, September 15, 2018), 6.

${ }^{3}$ Leo Laba Lajar, "Sekularisasi Dan Sekularisme: Autonomi Terhadap Allah?," in Iman Dan Ilmu: Refleksi Iman Atas Masalah-Masalah Aktual, ed. Alex Seran and Embu Henriquez (Yogyakarta: Kanisius, 1994), 30-47.

${ }^{4}$ E.G. Singgih, Menguak Isolasi, Menjalin Relasi: Teologi Kristen dan Tantangan Dunia Postmodern, (Jakarta: BPK Gunung Mulia, 2009), 17-30 
situasi batas manusia dan terpanggil memaknai hidup di hari ini menjadi hidup yang semakin beradab. Tulisan ini akan menggunakan urutan pembahasan sebagai berikut. Pertama-tama dijelaskan ketegangan antara teori evolusi dan iman. Kemudian pandangan Kitab Kejadian tentang penciptaan. Selanjutnya sintesis Pierre Teilhard de Chardin tentang Kristus Kosmik sebagai puncak evolusi manusia. Berikutnya dipaparkan jejak-jejak evolusi dalam rekayasa genetika dan protein melalui para peraih nobel 2018. Akhirnya tulisan ini ditutup dengan beberapa kesimpulan berupa rekomendasi dialog antara iman dan ilmu.

\section{Evolusi dan Iman Kristen}

Pada 1951, Gereja Katolik di masa Paus Pius XII mengemukakan dukungannya terhadap teori "Big Bang", karena dianggap cocok dengan pemahaman di dalam Kitab Suci Kristiani, khususnya di dalam kitab Kejadian 1 mengenai terciptanya alam semesta. ${ }^{5}$ Pius XII senang dengan penemuan teori Big Bang, karena kalau dunia ini mempunyai awal mula, terbuka kemungkinan bahwa dunia ini ada penciptanya. Pandangan terakhir ini dikuatkan oleh Paus Yohanes Paulus II $^{6}$, yang pada 1981 dalam forum kosmologi para Yesuit, mengatakan tidak berkeberatan apabila para ilmuwan menyelidiki alam semesta pasca Big Bang, tetapi janganlah memeriksa Big Bang sendiri karena hal itu adalah the moment of Creation dan merupakan karya ilahi.

Sebelumnya Pius XII dalam ensiklik Humani Generis 1950 menjadi Paus pertama yang menyatakan bahwa ajaran evolusi tidak harus dianggap bertentangan dengan iman Kristiani sejauh itu menyangkut hal tubuh manusia, sementara tentang jiwa diciptakan oleh Allah.7 Lagi-lagi Paus Yohanes Paulus II mempertegas pendapat Pius XII dengan mengatakan:

Sekarang, hampir setengah abad setelah penerbitan [Humani Generis], pengetahuan baru telah membawa pada pengakuan teori evolusi sebagai lebih dari hanya sekadar hipotesis. Memang luar biasa bahwa teori ini telah makin banyak diterima oleh para peneliti, mengikuti serangkaian penemuan berbagai bidang pengetahuan. Titik temu, yang tidak dicari atau pun dibuat, dari hasil-hasil kerja yang dilakukan secara terpisah itu sendiri merupakan argumen signifikan yang mendukung teori ini. ${ }^{8}$

Apakah dua pernyataan dari dua Paus di atas harus dianggap sebagai kekalahan iman atau teologi dari kekuatan ilmu pengetahuan? Atau menjadi titik balik teologi -dalam

5Ian G. Barbour, "Penciptaan dan Kosmologi”, dalam Sains dan Agama dalam Konteks Zaman Ini, ed. Louis Leahy, (Yogyakarta: Kanisius, 1997), 56. Singgih, Menguak Isolasi, Menjalin Relasi, 19, 21. Lihat juga E.G. Singgih, "Sifat Antropologis Sains dan Teologi: Terbatas sih, tetapi...", dalam Dari Kosmologi ke Dialog: Mengenal Batas Pengetahuan, Menentang Fanatisme, peny. Ihsan Ali-Fauzi dan Zainal Abidin Bagir, (Jakarta: Mizan Publika, 2011), 180.

${ }^{6}$ Singgih, Menguak Isolasi, Menjalin Relasi, 27.

${ }^{7}$ Pope Pius XII, Humani Generis: False Trends in Modern Teaching, (London: Catholic Truth Society, 1950), 4. Berthold A. Pareira, "Penciptaan Menurut Kej. 1-2 dan Teori Evolusi", Ekawarta, No. 04 \& 05, XVIII, (Juli-Oktober 1998):12-18. Joseph V. Kopp, Teilhard de Chardin: Sintese Baru tentang Evolusi, (Yogyakarta, Kanisius, 1983), 13-14

${ }^{8}$ Martinez J. Hewlett, "Evolusi Biologis dalam Sains dan Teologi”, dalam Menjembatani Sains dan Agama, peny. Ted Peters dan Gaymon Bennett, Terj. Jessica Christiana Pattinasarany, (Jakarta: BPK Gunung Mulia dan CTNS, 2006), 107. 
hal ini Gereja Katolik - untuk makin terbuka pada perkembangan dunia sains setelah lama menampilkan diri sebagai the queen of sciences yang menjadikan pengetahuan lain sebagai "hamba teologi" (ancilla theologiae), tidak ramah dan bersikap fundamentalis (menurut pemahaman Ptolemaistik-Aristotelian-alkitabiah) hingga memakan korban antara lain Galileo Galilei (1564-1642). ${ }^{9}$ Ironis bahwa baru 1992 Vatikan di masa Paus Yohanes Paulus II secara publik meminta maaf atas kesalahan sejarah "pemberangusan" karya Galileo dan di masa Paus Benediktus XVI memulihkan namanya dengan mengakui kebenaran bahwa bumilah yang beredar mengelilingi matahari sebagai pusat. ${ }^{10}$

Pada 1857 Charles R. Darwin (1809-1882) menerbitkan bukunya On the Origin of Species by Means of Natural Selection. ${ }^{11}$ Karya ini sebetulnya karya yang dipublikasikan tergesa-gesa. Ia takut kedahuluan dari karya A.R. Wallace yang sempat ia baca, yang mengembangkan teori seleksi yang sama dengan yang Darwin kembangkan. Sebetulnya apa yang dikemukakan Darwin bukan sesuatu yang sama sekali baru. ${ }^{12}$ Kendati demikian, teori Darwin seperti sebuah bom rohani. Karya Darwin On the Origin of Species, didasarkan atas perjalanan penelitiannya yang terkenal di atas kapal HMS Beagle, terutama ke Kepulauan Galapagos, pesisir barat benua Amerika Selatan. Darwin menguraikan teorinya bahwa semua organisme-organisme di bumi berasal dari organisme-organisme yang sederhana yang kemudian "berkembang" (evolusi) menjadi beraneka organisme-organisme nabati dan hewani yang hampir tak terhingga, yang kita kenal sekarang. Mekanisme perkembangan itu adalah "kekuatan" penyesuaian organisme-organisme pada kondisi lingkungan yang diwariskan kepada keturunan. ${ }^{13}$ Sedangkan persaingan (struggle for life) berasal dari proses "memilih" (seleksi) jenisjenis yang paling cocok dan menyingkirkan yang kurang sesuai (survival of the fittest).

Kesimpulan yang mengejutkan, yang dilakukan oleh Darwin sendiri ${ }^{14}$, yaitu bahwa manusia pun merupakan salah satu hasil evolusi. Jadi manusia tidak begitu saja muncul dari kekosongan atau dari mana pun, seakan-akan ia berasal dari luar bumi ditempatkan ke dalamnya, melainkan ia adalah salah satu produk evolusi kehidupan di bumi yang sudah berjalan sejak ratusan juta tahun. Menurut teori evolusi, manusia berasal dari segerombolan binatang (sebuah populasi), bukan seperti yang diterima dari agama-agama, berasal dari satu pasang laki-laki dan perempuan (Adam dan Hawa). Lebih tepatnya, manusia adalah saudara kandung simpanse dan gorilla; populer disebut bahwa "manusia berasal dari kera."

9Lembaga Biblika Indonesia, "Fundamentalisme Kitab Suci tentang Akhir Zaman”, Ekawarta, No. 01, XVIII, (Januari-Februari 1998): 6-14. E.G. Singgih, Dunia yang Bermakna: Kumpulan Karangan Tafsir Perjanjian Lama, (Jakarta: Persetia, 1999), 270.

${ }^{10}$ Muhsin, "Vatikan Rehabilitasi Galileo", https://muhsinlabib.com/akhirnya-vatikan-rehabilitasinama-galileo/ (diakses 21 Desember 2018, pkl. $11.00 \mathrm{Wib}$ ).

11Franz Magnis-Suseno, "Evolusi dan Iman", dalam Iman dan Ilmu: Refleksi Iman Atas Masalahmasalah Aktual, peny. Alex Seran dan Embu Henriquez, (Yogyakarta: Kanisius, 1994), 11-29 (11, 13).

${ }^{12}$ Kopp, Teilhard de Chardin, 10-11.

${ }^{13}$ Hewlett, "Evolusi Biologis dalam Sains dan Teologi", 100.

14Magnis-Suseno, "Evolusi dan Iman", 11-12. 
Dari sekian pemikiran Darwin, terdapat tiga teorinya yang mempunyai dampak sangat dahsyat. ${ }^{15}$ Pertama, pandangan bahwa manusia tergolong ke dalam binatang, membalik pandangan yang sudah umum bahwa manusia adalah raja karena merupakan mahkota semua ciptaan. Sebagai raja ia berkuasa atas semua makhluk hidup lainnya. Kedua, shok dengan pernyataan bahwa "manusia berasal dari kera", segera digeser oleh kesadaran bahwa gagasan evolusi sendiri mengasyikkan, karena mendudukkan kembali manusia menjadi "produk tertinggi alam". Akibatnya, "Darwinisme sosial" muncul, yaitu paham evolusi ini memberi legitimasi bagi bangsa, ras atau kelas sosial yang lebih kuat untuk menguasai yang lebih lemah. Ketiga, Darwinisme mengklaim bahwa pemikiran teleologis tidak diperlukan lagi. Pemikiran teleologis adalah pemikiran bahwa hukumhukum alam, termasuk yang terkait dengan makhluk hidup, hanya dapat dijelaskan sebagai keterarahan pada tujuan. Teleologis mengandaikan bahwa sang Pencipta diperlukan. Sebaliknya, Darwinisme mengatakan bahwa seluruh perkembangan yang ada terjadi secara kebetulan, tanpa rencana, dan menurut prinsip seleksi di mana yang terbaik dan terkuat yang dapat survive -berlaku struggle for life dan survival of the fittest. Sehingga teorinya menyimpulkan bahwa sang Pencipta tidak diperlukan.

Teori evolusi terus menjadi kontroversi dan memunculkan pertanyaan-pertanyaan mendasar. Secara teologis, bagaimana keyakinan ilmiah akan adanya evolusi dapat disesuaikan dengan wahyu tentang penciptaan manusia pertama? Dan secara filosofis, bagaimana evolusi dari yang lebih rendah ke yang lebih tinggi dapat dipikirkan?16 Uraian berikut akan mendiskusikan jawaban atas pertanyaan teologis di bawah sub judul "Evolusi dan Wahyu", sementara pertanyaan filosofis akan dibahas di sub judul berikutnya "Sintesis Teilhard de Chardin."

\section{Penciptaan Menurut Wahyu}

Menurut Kitab Kejadian, manusia pertama diciptakan secara khusus. ${ }^{17}$ Penciptaan menurut pasal 1 terjadi dalam enam hari dan manusia diciptakan sebagai makhluk terakhir. Sedangkan menurut pasal 2, manusia diciptakan dulu dari tanah, kemudian Allah menciptakan taman Eden dan menempatkan manusia di dalamnya, kemudian menciptakan binatang dan akhirnya menciptakan perempuan dari "rusuk" Adam sehingga manusia menjadi laki-laki dan perempuan.

Bagaimana teori evolusi dapat didamaikan dengan ajaran penciptaan dalam Kitab Kejadian? Menurut Frans Magnis-Suseno terdapat dua gagasan untuk menjelaskannya. Pertama adalah prinsip, dan kedua adalah pertimbangan eksegetis. ${ }^{18}$ Secara prinsipil, gagasan penciptaan adalah sangat sederhana. Alkitab berintikan Sabda Allah. Alkitab bukan buku ilmu alam atau buku ilmu sejarah. Segala yang ditulisnya tentang keadaan dunia dan manusia menggambarkan pengertian pengarangnya, diser-tai keterbatasan mereka. Yang mau dikatakan bahwa semuanya diciptakan oleh Allah. ${ }^{19}$ Alkitab tidak

\footnotetext{
15Magnis-Suseno, “Evolusi dan Iman”, 14-15. Singgih, Dunia yang Bermakna, 271.

16Magnis-Suseno, "Evolusi dan Iman", 24.

17Ibid., 25.

18Ibid.

191Pareira, "Penciptaan Menurut Kej. 1-2 dan Teori Evolusi”, 14, 16. Magnis-Suseno, "Evolusi dan
} Iman", 26. 
dimaksudkan untuk menggantikan usaha manusia untuk mencari pengetahuan tentang keadaan dunia ini, baik secara kimiawi maupun biologis. Dengan demikian, manusia hasil evolusi tidak kurang diciptakan Allah daripada manusia yang dibentuk dari tanah.

Secara eksegetis, terdapat dua cerita tentang penciptaan dalam Alkitab. ${ }^{20}$ Yang pertama tentang penciptaan dunia (Kej. 1:1-2:4a) dan kedua tentang penciptaan manusia (Kej. 2:4b-25). Dalam buku-buku pembimbing dikemukakan bahwa Kejadian 1 berasal dari tradisi "P" dan Kejadian 2 dari tradisi "Y". Secara naratif, ${ }^{21}$ kisah penciptaan yang dimulai dari Kejadian 1 sampai 11, maka Kejadian 1:26-28 dapat dianggap sebagai statement umum tentang penciptaan manusia yang terdiri dari laki-laki dan perempuan, sedangkan Kejadian 2:7 dan seterusnya dapat dianggap sebagai perincian dari penciptaan tersebut, yang memulainya dari laki-laki kemudian perempuan dan akhirnya anak-anak dan keturunannya. Pola yang sama dapat dilihat pada Kejadian 1:1 yang mulai dengan statement umum tentang penciptaan alam semesta (langit dan bumi) yang kemudian disusuli dengan perinciannya.

Kejadian 1:1-2:4a adalah suatu cerita tentang penciptaan dunia. Setiap perbuatan Allah dibuka dengan pernyataan "Berfirmanlah Allah" (1:3, 6, 9, 11, 14, 20, 24, 26). Firman Allah semuanya berbentuk perintah: "Jadilah/Hendaklah...” (1:3, 6, 11, 14-15, 20, 21), kecuali waktu menciptakan manusia: "Baiklah kita..." (1:26). Apa yang difirmankan (diperintahkan) Allah juga langsung terjadi secara creatio ex nihilo $(1: 3,7,9$, 11, 15, 24). Kendati Singgih mengatakan bahwa narasi Kejadian lebih menjelaskan ex nihilo nihil fit (dari ketiadaan tidak mungkin ada yang terjadi atau tercipta). ${ }^{22}$ Kata "Baiklah kita..." menggambarkan bahwa Allah sedang berunding dengan pikirannya sendiri. Manusia itu makhluk unik, karena ia diciptakan setelah melalui pertimbangan yang matang, hanya ia yang satu-satunya disebut gambar Allah.

Pada waktu penciptaan dikatakan bahwa manusia (ha' adam) dibentuk (dari kata yatsar) dari debu tanah (afar min ha' adamah). Sementara itu, kata yang digunakan untuk melukiskan penciptaan perempuan adalah "membangun." Dalam bahasa Ibrani "membangun" adalah banah, untuk menggambarkan pembuatan sesuatu yang "sophisticated". ${ }^{23}$ Perempuan dibuat dari bagian samping manusia -Ibrani-nya hatsela, "bagian samping" jadi bukan "rusuk" - bagian dari diri sendiri, itulah yang sepadan dengan dirinya laki-laki.

Dari penjelasan di atas, maka Kejadian 1:1-2:4a mau mengatakan bahwa: ${ }^{24}$ (1) seluruh alam semesta ini telah diciptakan oleh Allah dan tidak boleh ada yang disembah. Bagaimana semuanya ini terjadi tidak menjadi persoalan pengarang; (2) manusia diciptakan Tuhan segambar dengan Allah tidak berarti ia adalah "mahkota

20Pareira, "Penciptaan Menurut Kej. 1-2 dan Teori Evolusi”, 12-16. Magnis-Suseno, "Evolusi dan Iman", 26-27.

${ }^{21}$ Singgih, Dunia yang Bermakna, 121.

${ }^{22}$ E.G. Singgih, Dua Konteks: Tafsir-tafsir Perjanjian Lama sebagai Respons atas Perjalanan Reformasi di Indonesia, (Jakarta: BPK Gunung Mulia, 2012), 206-249.

${ }^{23}$ Singgih, Dunia yang Bermakna, 117-118, 124.

${ }^{24}$ Singgih, Dunia yang Bermakna, 117-118, 271-272. Singgih, Menguak Isolasi, Menjalin Relasi, xiii. Pareira, "Penciptaan Menurut Kej. 1-2 dan Teori Evolusi”, 14-15. 
penciptaan" sehingga superior daripada penciptaan yang lain. Manusia itu makhluk unik, ia diciptakan setelah melalui pertimbangan yang matang, hanya ia yang satusatunya disebut gambar Allah, tetapi tidak berada di atas ciptaan yang lain; (3) pendeskripsian manusia sebagai yang berasal dari tanah bermaksud menyampaikan bahwa manusia benar-benar makhluk fana dan dapat mati; (4) Allah adalah tujuan dari segala ciptaan dan karya penciptaan. Itu berarti daya-daya yang bekerja melalui variasi kebetulan -seperti yang dikatakan oleh teori evolusi- hingga proses penciptaan terbebas dari Pencipta, tidak dapat diterima, atau setidaknya ruangnya dimungkinkan ada dalam pandangan dunia sains. Penjelasan-penjelasan di atas, kata Singgih, cukup melegakan sehingga di kalangan Kristen masalah evolusi tidak terlalu meresahkan lagi.

\section{Sintesis Teilhard de Chardin}

Pierre Teilhard de Chardin lahir di Auvergne, Perancis, 1880. Sesudah belajar filsafat dan teologi di Jersey, Inggris, ia mengajar di salah satu kolose Jesuit di Kairo, dan sesudah itu ditahbiskan menjadi imam Jesuit. Sesudah ditahbiskan, 1912, ia mulai belajar secara sistematis ilmu-ilmu tentang bumi dan hidup. Ketika Perang Dunia I meletus (1914-1918), ia berangkat sebagai pastor tentara di Afrika Utara. Dari 1922-1926, ia mengajar geologi di Institut Catholique de Paris. Sejak 1923 ia bekerja di Cina serta di seluruh Timur Jauh, di sana ia menjalani 40 tahun hidupnya, sampai Perang Dunia II berakhir. Ia ikut menemukan manusia purba Sinanthropus di China. ${ }^{25}$ Ia sempat menjabat sebagai direktur penelitian antropologis di New York untuk misi-misi di Afrika Selatan dan selatan Sahara. Di New York inilah Teilhard meninggal dunia pada 1955 di usia 75 tahun. ${ }^{26}$

Mengapa Teilhard menimbulkan perhatian dan minat besar? Karena dia berhasil mencapai sebuah dimensi yang dalam sekali di dalam batin manusia kontemporer, yaitu mencarikan sintesis dan solusi konflik ilmu dan iman.27 Pemikiran Teilhard mempengaruhi pemikiran kontemporer karena ia nampak sangat profetis, sekaligus banyak disalahpahami termasuk oleh Vatikan. ${ }^{28}$

Sintesis adalah usaha Teilhard dalam rangka mengakhiri kontradiksi antara iman Kristiani dan teori evolusi untuk konteks manusia modern. Sekalipun -dengan mengutip H. Berkhof- Gerrit Singgih bisa tidak sependapat dengan Teilhard de Chardin. ${ }^{29}$ Pada 1970-an memang banyak muncul literatur di kalangan Kristen yang menyinggung iman Kristen dan evolusi. Menurut Singgih yang tidak sependapat, usaha pengungkapan secara evolusioner tidaklah berarti bahwa perbedaan antara pemahaman tentang penciptaan dengan pemahaman evolusi itu terselesaikan. Lebih baik menempuh jalan keluar bahwa penciptaan adalah termasuk bahasa religius melalui peninjauan kembali sikap kita terhadap Alkitab. Bahasa religius berbeda

25Pierre Teilhard de Chardin, The Phenomenon of Man, trans. Bernard Wall, (London: Fontana Books, 1965), 212-220.

${ }^{26}$ Leahy, "Pandangan Dunia Pierre Teilhard de Chardin", 37. Kopp, Teilhard de Chardin, 23.

${ }^{27}$ Sir Julian Huxley, "Introduction", dalam De Chardin, The Phenomenon of Man, 11-30.

${ }^{28}$ Frans Magnis-Suseno, "Kata Pengantar", dalam Pierre Teilhard de Chardin, Gejala Manusia, terj. Ira Iramanto, (Jakarta: Hasta Mitra/Institute for ECOSOC Rights, 2004), xi-xvi.

${ }^{29}$ Singgih, Dunia yang Bermakna, 283-284. 
dengan bahasa ilmiah, meskipun objeknya bisa sama. Terhadap keduanya tidak berarti kita mengusahakan penyesuaian (konkordansi) bahkan sintesis, juga tidak berarti suatu perbedaan mutlak antara iman dan ilmu. Jelasnya kepelbagaian world view perlu dihargai.

Teilhard membagi sejarah alam (bumi) dalam tiga tahap besar, yaitu geogenesis atau terjadinya bumi dengan segala unsur-unsur kimia di dalamnya, biogenesis atau lahirnya makhluk hidup di muka bumi, dan noogenesis atau lahirnya kesadaran pada makhluk hidup yang disebut manusia. ${ }^{30}$ Dengan demikian, evolusi di bumi tidak hanya berhenti pada berkembangnya variasi makhluk hidup dari hewan bersel satu menjadi hewan bersel banyak dan kompleks seperti manusia -seperti disangkakan oleh Darwin- tetapi evolusi berlangsung pada tataran kesadaran. Yang dimaksud kesadaran (noosphere) setara dengan kesadaran pada manusia. Oleh Teilhard, kesadaran disebut sebagai "hakikat batin". ${ }^{31}$ Inilah evolusi noosphere, bahwa manusia akan lebih menjadi manusia. Proses ini disebut juga hominisasi.

Evolusi, menurut Teilhard, pertama-tama bukan perubahan dan perkembangan tataran jasmani, tetapi tataran rohani atau psikis atau jiwa, yaitu adanya kehendak yang kuat dari kesadaran untuk mencapai puncak evolusinya. "Evolution = rise of consciousness", kata Teilhard. ${ }^{32}$ Inilah yang terjadi pada manusia. Manusia adalah puncak yang telah menjadi tujuan dari segala usaha biologis di dunia ini. Manusia adalah bunga evolusi. Kesadaran manusia mempunyai tiga ciri utama: ${ }^{33}$ (1) kemampuan memusatkan apa yang terjadi di luar kepada dirinya; (2) kemampuan belajar; (3) kemampuan dipersekutukan dengan orang lain. Pandangan Teilhard bahwa yang berevolusi pertama-tama adalah jiwa nampaknya mendukung ensiklik Humani Generis Pius XII, yang mengatakan bahwa "asal-usul badan manusia berasal dari makhluk hidup lainnya yang sudah ada" dan menambahkan bahwa "penciptaan jiwa langsung oleh Tuhan".34 Manusia tidak hanya merupakan fase terakhir dari penciptaan, tetapi juga merupakan sebab yang terdalam mengapa semua perkembangan harus terjadi. Mengapa? Karena hanya manusia yang dapat memberi arti kepada setiap batu, setiap tumbuhan, setiap binatang dan seluruh alam semesta.

Apakah manusia berhenti berevolusi? Tidak! Menurut Teilhard, evolusi akan selalu berupa suatu penambahan "kesadaran". Teilhard menamakan sasaran evolusi ini sebagai Titik Omega.35 Omega sendiri adalah suatu "ego" super pribadi. Olehnya, manusia menjadi terhubungkan dengan sesamanya. Dari sinilah muncul spiritualitas Teilhard sebagai interpretasinya atas latihan-latihan rohani Ignasius dalam kesadaran

\footnotetext{
${ }^{30}$ De Chardin, The Phenomenon of Man, 201. Kopp, Teilhard de Chardin, 35. Risanto, "Darwin Mengamati, Teilhard Merefleksi", 38.

31De Chardin, The Phenomenon of Man, 200. Kopp, Teilhard de Chardin, 28, 40.

32De Chardin, The Phenomenon of Man, 268. Kopp, Teilhard de Chardin, 31.

${ }^{33}$ De Chardin, The Phenomenon of Man, 309.

${ }^{34}$ Pope Pius XII, Humani Generis, 4. Kopp, Teilhard de Chardin, 38.

35De Chardin, The Phenomenon of Man, 285, 319. Kopp, Teilhard de Chardin, 44.
} 
akan ilmu pengetahuan dan evolusi. ${ }^{36}$ Inilah gerakan sentripetal yang daya tariknya adalah cinta kasih. Bagaimana cinta kasih dapat dibuktikan secara empiris? ${ }^{37}$ Menurut Teilhard justru cinta-kasih itu nyata dalam setiap unsur yang membentuk alam semesta. Semua unsur alam semesta pun bekerja menurut cinta-kasih itu.

Terkait dengan teologi penciptaan, Teilhard de Chardin menjelaskan dalam kaitannya dengan Alfa dan Omega (awal dan akhir) sebagai sebuah proses evolusi. Menurutnya, Alfa (sebagai awal) adalah Alfa yang bekerja dan berproses dalam tindakan penciptaan; sehingga dalam tindakan penciptaan tidak ada sesuatu yang tiba-tiba akan ada begitu saja. Teilhard menolak konsep creatio ex nihilo. Baginya, tindakan penciptaan itu terus berproses, tetap berlangsung dan selalu akan terus berlangsung (creatio continua); sehingga tindakan penciptaan yang dikerjakan oleh Sang Alfa itu adalah tindakan yang terus dan masih berproses. ${ }^{38}$ Alur berpikir Teilhard terkait penciptaan juga bergerak dari cara pandang antroposentris kepada kosmosentris; sebab teorinya tentang evolusi pada dasarnya menempatkan manusia sebagai hasil (sementara) dari proses evolusi.

Akhirnya Teilhard berpaling kepada fenomena Kristus. ${ }^{39}$ Penciptaan Tuhan itu memuncak melalui kembalinya makhluk-makhluk kepada Tuhan. Allah-menjadimanusia adalah fase terakhir dari pengembalian itu. Sebagai Allah-menjadi-manusia, Kristus sekaligus menjadi sumbu dan tujuan akhir keselamatan. Ia-lah makhluk tertinggi, yang menjadi cita-cita pemribadian maju umat manusia. Kristus, Allahmenjadi-manusia, dapat memenuhi fungsi Titik Omega pada taraf tertinggi. Refleksi Teilhard mengenai Titik Omega berkembang terutama pada Perang Dunia I hingga akhir hayatnya pada 1955.40 Dengan begini, Teilhard berbicara ditataran kosmis: mengambil keluar tokoh Kristus dari bingkai sejarah yang sempit, yang telah dipaksakan kepada-Nya dan menonjolkan-Nya ke dalam alam semesta. Sehingga dari kosmogenesis muncul biogenesis, dari biogenesis muncul noogenesis dan akhirnya dari noogenesis muncul kristogenesis, yaitu sasaran mahkota dari semua ciptaan. Inilah yang disebut Kristus kosmik. Di sini Kristus menjadi titik api dan penyempurna evolusi yang sejati. Dialah Tuan dari kosmos. ${ }^{41}$ Omnia per ipsum facta sunt, et sine ipso factum est nihil (melalui Dia dijadikan segala-galanya, dan tanpa Dia tak suatu pun dijadikan). Dia juga yang telah menang atas penghambat utama evolusi, yaitu materialisasi, yang hadir dalam perang dan ketidakpedulian pada sesama. Teilhard mencontohkan NAZI sebagai

\footnotetext{
36De Chardin, The Phenomenon of Man, 58-72. J.B. Banawiratma, "Spiritualitas Ignasius Loyola", dalam Spiritualitas dari Berbagai Tradisi, ed. J.B. Banawiratma \& Hendri M. Sendjaja, (Yogyakarta: Kanisius, 2017), 119.

${ }^{37}$ De Chardin, The Phenomenon of Man, 290-294. Risanto, "Darwin Mengamati, Teilhard Merefleksi", 42. Yumartana, "Jalan Kebahagiaan Teilhard de Chardin", 27-28.

${ }^{38}$ De Chardin, The Phenomenon of Man, 80. Kopp, Teilhard de Chardin, 37.

${ }^{39}$ De Chardin, The Phenomenon of Man, 324-327. Kopp, Teilhard de Chardin, 47. Francisco Bravo, Christ in the Thought of Teilhard de Chardin, trans. Cathryn B. Larme, (Notre Dame - London: University of Notre Dame Press, 1967), 35-47.

${ }^{40}$ Ath. Kristiono Purwadi, "Kristus Kosmik: Kristologi Modern Menurut Teilhard de Chardin”, Rohani, Th. XLVI, No. 12, (Desember 1999): 511.

${ }^{41}$ De Chardin, The Phenomenon of Man, 325. Thomas M. King, Teilhard de Chardin: The Way of the Christian Mystics, Vol. 6, (Wilmington: Delaware, 1988), 53. Kopp, Teilhard de Chardin, 48. Purwadi, "Kristus Kosmik", 508-510.
} 
puncak materialisasi dan pemujaan rasio yang membelenggu manusia dari kebebasannya untuk peduli kepada manusia lain. Materi adalah penghambat utama untuk melihat bayangan sendiri. Puncak evolusi adalah Kristus sebagai Titik Omega seluruh manusia dan alam semesta ini. Kristus menjadi bayangan yang dengan melihat-Nya manusia menemukan dirinya secara baru dan terbebaskan dari tuhan-tuhan materi.

\section{Pembahasann}

\section{Prinsip Evolusioner: Menapaki Jejak Evolusi dalam Rekayasa Genetika dan Protein}

Pada Sabtu, 6 Oktober 2018, Kompas menurunkan tulisan berjudul "Menapaki Jejak Evolusi." 42 Tulisan ini memuat tiga ilmuwan penerima hadiah Nobel bidang Kimia 2018, yaitu Frances Hamilton Arnold dari California Institute of Technology, Pasadena, AS; Sir Gregory Paul Winter dari Medical Research Council Laboratory of Molecular Biology, Cambridge, Inggris; dan George Pearson Smith dari University of Missouri, Columbia, AS. Ketiganya terinspirasi dengan kekuatan evolusi dan menggunakan prinsip-prinsip yang sama, yaitu perubahan genetik dan seleksi untuk meningkatkan protein yang menjawab persoalan kimia manusia. ${ }^{43}$ Hasil kerja mereka antara lain bahan bakar ramah lingkungan dan obat-obat baru untuk mengobati penyakit auto-imun dan kanker.

Frances Hamilton Arnold mengembangkan rekayasa protein dalam bidang biologi sintesis. ${ }^{44}$ Temuannya dipakai untuk membuat katalisator baru, digunakan di pabrik bahan kimia, pabrik obat, dan produksi bahan bakar terbarukan untuk sektor transportasi yang lebih hijau. Pada 1993, ia melakukan proses "evolusi langsung enzim" dan berhasil menciptakan prototipe enzim yang bisa mengubah gula secara sederhana menjadi isobutanol, sebuah zat yang digunakan dalam proses produksi biofuel dan plastik. Sementara itu pada 2016, Gregory Winter meneliti dan menemukan antibodi yang bisa digunakan manusia, yaitu antibodi monoklon terapeutik (therapeutic monoclonal antibodies). ${ }^{45}$ Terapi antibodi digunakan untuk mengobati kanker dan penyakit-penyakit seperti artritis rematik dan sklerosis ganda. Temuannya ini bisa digunakan untuk mencegah penyakit dan menyelamatkan nyawa manusia.

Terakhir, George Pearson Smith, pada 1985 mengembangkan sebuah metode bakteriofag. ${ }^{46}$ Bakteriofag adalah virus yang dapat mematikan bakteri dan mengandung DNA (deoxyribonucleic acid) dan RNA (ribonucleic acid) untuk mendapatkan antibodi. Smith menggunakan bakteri untuk mengarahkan evolusi antibodi yang melawan penyakit dengan tujuan menemukan obat baru yang dapat menyembuhkan berbagai penyakit kronis. Dengan Arnold, Winter dan Smith menggunakan prinsip evolusi untuk menciptakan enzim, antibodi, obat, bahan-bahan kimia ramah lingkungan, dan mencegah penyakit serta menyelamatkan nyawa, maka perkembangan-perkembangan

\footnotetext{
42Brigitta Isworo Laksmi, "Menapaki Jejak Evolusi”, Kompas, (6 Oktober 2018):16.

43Ibid.

${ }^{44}$ Ibid.

45 Ibid.

46Ibid.
} 
akhir dari ilmu pengetahuan kian melepaskan sifatnya yang deterministik (segala sesuatu menuju pada titik akhir yang dalam agama disebut Tuhan) dan menerima prinsip-prinsip ketidakpastian. Inilah gambaran dunia kontemporer, yaitu gambaran dunia evolusioner. ${ }^{47}$ Penerimaan gambaran dunia evolusioner ini tidaklah berarti bahwa perbedaan antara pemahaman tentang penciptaan (berasal dari agama) dengan pemahaman evolusi (berasal dari ilmu) berarti terselesaikan. Lalu apa jalan keluarnya?

Pakar sains sekaligus teolog, Ian G. Barbour, dalam Issues in Sciences and Religion, telah mengatakan empat tipologi hubungan antara agama dan sains: konflik, independensi, dialog dan integrasi. ${ }^{48}$ Tetapi, menurut Singgih, Indonesia baru mengenal tipologi konflik dan independensi saja, belum menyentuh kedua tipologi yang lain, dialog dan integrasi. ${ }^{49}$ Jika ketegangan bahkan konflik ini tidak pernah diatasi atau dilampaui, mungkin kita tidak akan pernah mendapatkan manfaat dari hasil dialog antara ilmu dan teologi. Bahkan sebelum bicara tentang manfaat, tahapan mencapai posisi dialogis di antara keduanya pun hanya mungkin terjadi jika keduanya mengakui keterbatasan masing-masing, bukan sebaliknya ketidakterbatasannya. Seperti pendapat Singgih,50 gambaran dunia sains dan gambaran dunia agama, termasuk gambaran dunia budaya bukanlah antitesa. Itu berarti sikap menghargai masing-masing gambaran dunia itu sekaligus berarti mengakui keterbatasannya. Kita mengapresiasi tanpa mengeliminasi. Justru karena masing-masing terbatas, maka satu sama lain memiliki kebutuhan untuk berkomunikasi dan berdialog. Keduanya sama-sama menolong untuk tidak hanya melihat yang riil (konkret, rasional) dari manusia tetapi yang melampaui itu, yaitu bayangan tentang makhluk fana yang merindukan kehidupan kekal.

Fungsi bayangan mengingatkan kita pada apa yang Gerrit Singgih pernah katakan tentang “Merosotnya 'Bayangan' dalam Bayangan Orang Indonesia”. ${ }^{51}$ Menurut Singgih, semula pemahaman mengenai konsep maya -yang diperoleh dari agama dan filsafat Hindu - sebagai bayangan atau khayalan belaka, kini tidak perlu lagi diantitesakan dengan pemahaman agama Kristen misalnya, yang dianggap bukan agama bayangan atau agama khayalan melainkan agama riil atau konkret. Inilah oposisi biner yang sengaja atau tidak diabadikan, bahwa agama Kristen adalah agama riil atau konkret (biasanya dekat dengan kesempurnaan dan rasional) dilawankan dengan semua agama non-Kristen sebagai agama khayalan atau bayangan (biasanya dekat dengan ketidaksempurnaan dan tidak rasional). Singgih mengatakan bahwa oposisi biner tersebut siasia saja, karena bayangan atau khayalan pun punya makna positif sebagai tanda bahwa dengan melihat bayangannya sendiri manusia tetaplah manusia bukan drakula, yaitu makhluk yang lebih jahat dari vampir. Fungsi bayangan adalah memberi peringatan pada manusia agar tidak menjadi drakula, terlebih di era revolusi keempat ini.

\footnotetext{
${ }^{47}$ Singgih, Dunia yang Bermakna, 283.

${ }^{48}$ Ian G. Barbour, Issues in Science and Religion, (London: SCM Press Ltd., 1966), 115-134.

${ }^{49}$ Singgih, Menguak Isolasi, Menjalin Relasi, 17-18.

${ }^{50}$ E.G. Singgih, "Kata Pengantar: Menjembatani Sains dan Agama dalam Konteks Indonesia”, dalam Menjembatani Sains dan Agama, peny. Ted Peters dan Gaymon Bennett, terj. Jessica Christiana Pattinasarany, (Jakarta: BPK Gunung Mulia, 2006), xiii-xix (xix).

${ }^{51}$ E.G. Singgih, “Merosotnya 'Bayangan' dalam Bayangan Orang Indonesia”, Gema Teologi, Vol. 37, No. 2, (Oktober 2013): 207-218.
} 
Bayangan atau khayalan adalah bagian penting mendapatkan pembebasan dari dunia riil yang sangat memuja materi. Bayangan atau khayalan adalah aspek misteri yang tidak boleh hilang dari kesadaran manusia di era pascamodern ini. Atau sebaliknya, jangan-jangan, seperti kata Teilhard, ${ }^{52}$ tanpa melihat bayangannya, manusia justru terus tertambat pada materi dan tidak pernah berevolusi dalam pendakian ke Titik Omega, yaitu pembebasan ke arah kemanusiaan yang sejati.

Ayu Utami dalam novelnya Lalita mengatakan, "Dia yang tidak bisa melihat bayangbayangnya sendiri, dia tidak akan mendapatkan pembebasan".53 Kalimat ini mengingatkan pada tokoh-tokoh yang menyerukan pembebasan dengan melihat kepada diri, termasuk bayangan-nya sendiri. Contohnya adalah Karl Barth. ${ }^{54}$ Paus Pius XII menyebut Barth sebagai teolog terbesar sesudah Thomas Aquinas. Barth diapresiasi karena membawa pemahaman baru pada teologi yang lebih terbuka dan mengakui sifat antropologis dari teologi. Barth adalah orang yang mengalami putaran besar dalam teologinya bukan mulai dari bawah (dari konteks), dia sengaja mulai dari atas, dari Tuhan. Menurutnya, Tuhan telah bersuara dan yang perlu kita lakukan adalah berdiam diri dan mendengar suara Tuhan lewat kitab suci. Kedengarannya seperti orang fundamentalis, padahal Barth adalah anti-fundamentalis. Ia dituduh sebagai teolog yang lari dari tantangan iman dalam konteks. Tetapi hidup Barth jelas berbeda. Ketika semua dosen bersumpah setia kepada Hitler, Barth menolak. Akibatnya dia dipecat. Ia pun menyebut Hitler sebagai "Anti-Christ". Ketika muncul "gereja yang mengaku" (Bekennende Kirche), yaitu mengakui Yesus dan tidak mengakui Hitler, Barth menjadi tokoh inspirasinya. Barth tetap konsekuen. Bukan hanya totalitarianisme Nazi yang ditentangnya tetapi semua bentuk totalitarianisme. Masalahnya terletak pada ideologi manusia yang sering dipertuhan. Kata Barth, tugas teologi adalah menelanjangi yang dipertuhan, berhala tersebut. Let God be God! Di waktu kemudian Barth mengubah orientasi teologinya dari atas sekarang mulai dari bawah. Barth 1 adalah "God", dan Barth 2 adalah "the humanity of God."

\section{Kesimpulan}

Kini Artificial Intelligence (AI) dianggap sebagai kelanjutan dari bekerjanya pandangan evolusioner. 55 Pertanyaan etis-nya, ke mana arah gelombang evolusioner ini membawa masyarakat? Jelas bahwa AI adalah sebuah bayangan yang menyimbolkan kewaspadaan pada potensi destruktif pada diri manusia. Sehingga pandangan dunia evolusioner memerlukan kerendahan hati untuk kembali pada sifat antropologis pengetahuan. ${ }^{56}$ Sifat antropologis ini sama artinya dengan kemampuan melihat bayangan sendiri. Melihat bayangan adalah kesadaran bahwa pemikirannya terbatas. Tetapi kesadaran ini

52 Pierre Teilhard de Chardin, The Phenomenon of Man, trans. Bernard Wall, (London: Fontana Books, 1965), 40, 336. Bayu Risanto, “Darwin Mengamati, Teilhard Merefleksi”, Basis, No. 05-06, Th. ke59, (2010):38-43 (43).

53 Ayu Utami, Lalita, (Jakarta: Kepustakaan Populer Gramedia, 2012), 104, 232, 233.

54 Singgih, "Sifat Antropologis Sains dan Teologi", 188-191.

55 Lance Wang, "Kecerdasan Buatan dan Kota Cerdas”, Kompas, (19 Oktober 2018):7. Widodo Budiharto, "Dampak Kecerdasan Buatan bagi Indonesia”, Kompas, (19 Oktober 2018):6.

56 Singgih, "Sifat Antropologis Sains dan Teologi", 184. 
muncul karena sebelumnya orang telah kehilangan batas akibat terobsesi pada yang riil, materi, yang dipertuhan. Begitu pula dampak etis tidak ditentukan oleh konsepnya, tetapi oleh hidup dari orang-orang yang menciptakan konsep-konsep ini. Barth berpikiran dogmatis, tetapi hidupnya sampai akhir adalah perlawanan habis-habisan terhadap segala sesuatu yang merusak kemanusiaan manusia, termasuk hal-hal yang dipertuhan. Inilah tugas ilmuwan sekaligus tugas teolog yang mempunyai keprihatinan sama. Puncak evolusi pada akhirnya terletak pada manusia yang diciptakan Allah sebagai makhluk yang unik, yang mampu melihat bayangan-nya sendiri agar tidak menjelma menjadi drakula serta terbebas dari tuhan-tuhan yang palsu dan dapat menghancurkan kemanusiaan.

\section{Referensi}

Bagir, Haidar. "Pendidikan Manusia Vs Kecerdasan Buatan". Kompas. (15 September 2018):7.

Banawiratma, J.B. "Spiritualitas Ignasius Loyola". Dalam Spiritualitas dari Berbagai Tradisi. Ed. J.B. Banawiratma \& Hendri M. Sendjaja. Yogyakarta: Kanisius, 2017.

Barbour, Ian G. "Penciptaan dan Kosmologi". Dalam Sains dan Agama dalam Konteks Zaman Ini. Ed. Louis Leahy. Yogyakarta: Kanisius, 1997. . Issues in Science and Religion. London: SCM Press Ltd., 1966.

Bravo, Francisco. Christ in the Thought of Teilhard de Chardin. Trans. Cathryn B. Larme. Notre Dame - London: University of Notre Dame Press, 1967.

Budiharto, Widodo. "Dampak Kecerdasan Buatan bagi Indonesia". Kompas. (19 Oktober 2018):6.

De Chardin, Pierre Teilhard. The Phenomenon of Man. Trans. Bernard Wall. London: Fontana Books, 1965.

Hewlett, Martinez J. "Evolusi Biologis dalam Sains dan Teologi". Dalam Menjembatani Sains dan Agama. Peny. Ted Peters dan Gaymon Bennett. Terj. Jessica Christiana Pattinasarany. Jakarta: BPK Gunung Mulia dan CTNS, 2006.

King, Thomas M. Teilhard de Chardin: The Way of the Christian Mystics. Vol. 6. Wilmington: Delaware, 1988.

Kopp, Joseph V. Teilhard de Chardin: Sintese Baru tentang Evolusi. Yogyakarta: Kanisius, 1983.

. Teilhard de Chardin: A New Synthesis of Evolution. New York: Deus Books Paulist Press, 1964.

Lajar, Leo Laba. "Sekularisasi dan Sekularisme: Autonomi terhadap Allah?” Dalam Iman dan Ilmu: Refleksi Iman Atas Masalah-masalah Aktual. Peny. Alex Seran dan Embu Henriquez. Yogyakarta: Kanisius, 1994.

Laksmi, Brigitta Isworo. “Menapaki Jejak Evolusi”. Kompas. (6 Oktober 2018):16.

Leahy, Louis. "Pandangan Dunia Pierre Teilhard de Chardin". Diskursus. Vol. 2, No. 1, (April 2003):35-56.

Lembaga Biblika Indonesia. "Fundamentalisme Kitab Suci tentang Akhir Zaman". Ekawarta. No. 01, XVIII, (Januari-Februari 1998):6-14.

Magnis-Suseno, Franz. "Kata Pengantar". Dalam Pierre Teilhard de Chardin. Gejala Manusia. Terj. Ira Iramanto. Jakarta: Hasta Mitra/Institute for ECOSOC Rights, 2004. . "Evolusi dan Iman". Dalam Iman dan Ilmu: Refleksi Iman Atas Masalah-masalah Aktual. Peny. Alex Seran dan Embu Henriquez. Yogyakarta: Kanisius, 1994. 
Muhsin, "Vatikan Rehabilitasi Galileo", https://muhsinlabib.com/akhirnya-vatikanrehabilitasi-nama-galileo/ (diakses 21 Desember 2018, pkl. 11.05 Wib).

Pareira, Berthold A. "Penciptaan Menurut Kej. 1-2 dan Teori Evolusi". Ekawarta. No. 04 \& 05, XVIII, (Juli-Oktober 1998):12-18.

Pope Pius XII. Humani Generis: False Trends in Modern Teaching. London: Catholic Truth Society, 1950.

Purwadi, Ath. Kristiono. "Kristus Kosmik: Kristologi Modern Menurut Teilhard de Chardin". Rohani. Th. XLVI, No. 12, (Desember 1999):507-514.

Risanto, Bayu. "Darwin Mengamati, Teilhard Merefleksi”. Basis. No. 05-06, Th. ke-59, (2010):38-43.

Singgih, E.G. "Merosotnya 'Bayangan' dalam Bayangan Orang Indonesia”. Gema Teologi. Vol. 37, No. 2, (Oktober 2013):207-218.

. Dua Konteks: Tafsir-tafsir Perjanjian Lama sebagai Respons atas Perjalanan Reformasi di Indonesia. Jakarta: BPK Gunung Mulia, 2012.

. "Sifat Antropologis Sains dan Teologi: Terbatas sih, tetapi...". Dalam Dari Kosmologi ke Dialog: Mengenal Batas Pengetahuan, Menentang Fanatisme. Peny. Ihsan Ali-Fauzi dan Zainal Abidin Bagir. Jakarta: Mizan Publika, 2011.

- Menguak Isolasi, Menjalin Relasi: Teologi Kristen dan Tantangan Dunia Postmodern. Jakarta: BPK Gunung Mulia, 2009.

. "Kata Pengantar: Menjembatani Sains dan Agama dalam Konteks Indonesia". Dalam Menjembatani Sains dan Agama. Peny. Ted Peters dan Gaymon Bennett. Terj. Jessica Christiana Pattinasarany. Jakarta: BPK Gunung Mulia, 2006.

. Dunia yang Bermakna: Kumpulan Karangan Tafsir Perjanjian Lama. Jakarta: Persetia, 1999.

Sudjatmiko, Budiman. “Inovasi dalam Revolusi 4.0”. Kompas. (15 September 2018):6.

Utami, Ayu. Lalita. Jakarta: Kepustakaan Populer Gramedia, 2012.

Wang, Lance. "Kecerdasan Buatan dan Kota Cerdas". Kompas. (19 Oktober 2018):7.

Wiseman, James A. "The Wisdom of Pierre Teilhard de Chardin". Chicago Studies. Vol. 38, No. 1, (Spring 1999):72-83.

Yumartana, M. "Jalan Kebahagiaan Teilhard de Chardin". Driyarkara. Th. XVI, No. 3, (1990):25-34. 